\title{
Increased Chromosomal Damage among Children in Proximity to an Industrial Zone
}

\author{
Nor Ashikin Sopian ${ }^{1}$, Juliana Jalaludin ${ }^{1,2^{*}}$, Tengku Zatil Aleyya Tengku Mayusi ${ }^{1}$, \\ Mohd Talib Latif ${ }^{3}$ \\ ${ }^{1}$ Department of Environmental and Occupational Health, Faculty of Medicine and Health Sciences, Universiti Putra \\ Malaysia, 43400 Serdang, Selangor, Malaysia \\ ${ }^{2}$ Faculty of Public Health, Airlangga University, 60115 Surabaya, East Java, Indonesia \\ ${ }^{3}$ Department of Earth Sciences and Environment, Faculty of Science and Technology, Universiti Kebangsaan Malaysia, \\ 43600 Bangi, Selangor, Malaysia
}

\begin{abstract}
This study aimed to investigate air pollutant exposure at five primary schools in Terengganu, Malaysia, and to assess the chromosomal damage among the students by evaluating 176 school children aged 10-11 years. Members of the exposed group lived close to the industrial zone, whereas those of the comparative group lived far from it. The parameters for the indoor air monitoring included suspended particulate matter, gaseous pollutants $\left(\mathrm{NO}_{2}\right.$ and $\left.\mathrm{SO}_{2}\right)$, and physical variables (temperature, relative humidity, and air velocity). Respiratory symptoms were assessed through questionnaires $(n=176)$, and a micronucleus assay was conducted on the buccal epithelial cells of 91 children. The findings showed that the air pollutant levels at the schools of the exposed group were significantly higher $(p<0.05)$ than those of the comparative group. The highest concentrations of $\mathrm{PM}_{1}, \mathrm{PM}_{2.5}$, and $\mathrm{PM}_{10}$ recorded at the exposed schools were 43.30, 44.83, and $60.83 \mu \mathrm{g} \mathrm{m}{ }^{-3}$, respectively. Coughing was the most significant recurring respiratory symptom among the children with a 2.52 odds ratio $(p<0.05)$. An average micronucleus frequency of $5.02 \pm 3.43 \mathrm{MN}$ per 1000 cells was displayed by children in the exposed group vs. $2.00 \pm 1.56 \mathrm{MN}$ per 1000 cells for the comparative group. After controlling for all possible confounding factors, these results strongly suggest that exposure to industrial air pollutants significantly influences the formation of micronuclei and increases the prevalence of respiratory symptoms among children living in proximity to an industrial area. Our study provides baseline data for genotoxic damage among such children in South East Asia specifically.
\end{abstract}

Keywords: Air pollutants; Chromosomal damage; Respiratory symptom; Children.

\section{INTRODUCTION}

The ever-increasing levels of air pollutants in many urban and industrial areas can result in adverse health impacts on people especially the young, the old, and the infirm. The young are especially susceptible due to their still developing physique as well as immature lungs and immune systems (Branco et al., 2014; Esposito et al., 2014; Korten et al., 2017). Prolonged exposure to high levels of air pollutants may increase the risk of developing cancer especially for those living near to heavy industries (Tsai et al., 2009; Yuan et al., 2018; Seifi et al., 2019). Many epidemiological studies have convincingly demonstrated the deterioration of air quality in schools in the proximity of big industrial areas, which

\footnotetext{
${ }^{*}$ Corresponding author.

Tel.: +603-89472397; Fax: +603-89472395

E-mail address: juliana@upm.edu.my
}

has led to significant respiratory health impacts especially of the acute nature (de Moraes et al., 2010; Godoi et al., 2013; Demirel et al., 2014; Rovira et al., 2014; Suhaimi et al., 2017). The proximity to industrial zone has been associated with a higher prevalence of respiratory symptoms, a high incidence of asthma attack, and reduction in lung function as compared to the population in non-industrial areas (Loyo-Berríos et al., 2007; Smargiassi et al., 2009; Wichmann et al., 2009; Ayuni et al., 2014). On the other hand, epidemiological studies on chronic health effects are scarcely documented among susceptible population especially children. Nevertheless, some studies have shown that children living in proximity to petrochemical installations in Taiwan experienced high mortality rate due to bone, brain, and blood cancer (Pan et al., 1994; Yu et al., 2005; Liu et al., 2008).

Chronic exposure to air pollutants has been frequently associated with genetic defects among children (Mielzynskasvach et al., 2013). Prolonged exposure to small or high concentrations of air pollutants may induce genetic toxicity and subsequently may increase the risk of cancer. Thus, 
biomarkers of genomic damage or chromosomal damage, such as micronucleus frequency, are widely used in cytogenetic epidemiological studies to predict the risk of cancer when exposed to polluted air (Pedersen et al., 2009; Mergener et al., 2014; de Oliveira Galvão et al., 2017; Sopian et al., 2017; Tan et al., 2017; Muhamad Daud et al., 2018). The micronucleus is derived from acentric chromosome fragments or whole chromosomes which have failed to migrate to spindle poles during the anaphase stage (Fenech, 2000). The presence of a small nucleus in a dividing cell provides a convenient indicator of genotoxicity due to chromosomal breakage and loss, known as chromosomal aberration. It is frequently assessed in human lymphocytes, erythrocytes, and exfoliated epithelial cells with different micronucleus frequency of similar exposure (de Oliveira Galvão et al., 2017; Tan et al., 2017; Muhamad Daud et al., 2018). The exfoliation of epithelial cells, such as buccal cells, is reported to be a minimally invasive method (proposed since 1983) as compared to lymphocytes and erythrocytes in indicating and determining the level of genetic damage due to inhalation and ingestion of xenobiotic substances (Holland et al., 2008; Thomas et al., 2011).

According to an in vivo genotoxicity study, Han et al (2013) demonstrated the increasing inhalation dose of nitrogen dioxide, $\mathrm{NO}_{2}$, significantly induced higher micronuclei frequencies. The mechanism involved might be contributed by metabolite reaction of nitrite and nitrate as it can damage cellular DNA and result in mutation or cancer. Inhalation of highly soluble sulfur dioxide, $\mathrm{SO}_{2}$, will be metabolized into sulfites, which can hinder DNA synthesis and induce chromosomal aberration. Besides that, oxidation of $\mathrm{SO}_{2}$ metabolite to sulfate may generate abundance of free radicals that can bind to DNA. The binding to DNA can cause crosslinking and DNA breaks (ATSDR, 1998). Meanwhile, the inhalation of particulate matter can induce the generation of reactive oxygen species, which break the phosphodiester backbone of DNA leading to DNA damage (Fenech et al., 2016).

To date, there have been limited study on the association between industrial air pollutant exposure and genotoxic outcome conducted among children in South East Asia. This study aims to evaluate the impact of industrial air pollutants on potential genotoxic outcome as indicated by the micronucleus frequency among primary school children living in the vicinity of industries.

\section{METHODS}

\section{Study Location}

Sampling was carried out from January to May 2017 at five selected schools and residential areas in Terengganu, a state in Peninsular Malaysia. A huge petrochemical complex in Kertih and Paka lies within the district of Dungun and Kemaman. The rapid development and economic growth in these districts since the 1980s have been primarily due to activities related to the oil and gas, and manufacturing industries. These activities boosted the human population in these districts with increasing numbers of immigrants moving into Terengganu to meet the job demand here.
According to the Department of Statistics, Malaysia (2010), Kemaman has a population of 161,959 , while Dungun has a population of 149,851 , of which $95 \%$ are Malays.

Despite experiencing rapid economic growth, both districts are facing the threats of air pollution due to emissions from industrial activities and the ever-increasing vehicles on the roads. This study was designed to assess the impact of air pollutant exposure among two groups of children in the two areas. The exposed group comprised children from primary schools located about $5 \mathrm{~km}$ from the industries, as correspond to the previous study (de Moraes et al., 2010). They lived nearby and attended three schools referred to as exposed schools, viz., S1, S2, and S3. The comparative group comprised children from primary schools located in Dungun, about $30 \mathrm{~km}$ from the industries. The comparative area was represented by two schools referred to as comparative schools, viz., $C 1$ and $C 2$, as shown in the map (Fig. 1). All the selected schools were located within $1 \mathrm{~km}$ from the main road. Meanwhile, 73 respondents' residences located nearby the exposed and comparative area were selected for home indoor air quality assessment.

\section{Respondent Recruitment}

This study involved 176 children aged between 10 and 11 years old. The number of respondents required was determined by a sample size calculation of two population means (Lwanga and Lemeshow, 1991) The selection of the respondents was based on stratified random sampling as was used in previous studies (Ayuni et al., 2014; Suhaimi et al., 2015). Validated questionnaires, adopted from Juliana et al. (2001) and Jalaludin et al. (2014), on socio-demographic patterns, respiratory symptoms, and home exposure assessment were randomly distributed to the primary school children. The section of home exposure assessment comprised questions on indoor smoking; building material finishes (walls, and floor); open burning; and window opening during cooking. Those children who met the inclusion and exclusion criteria (free from history of doctor-diagnosed chronic disease, radiotherapy or chemotherapy in the previous 12 months, or X-rays in the previous 3 months) were recruited for buccal cell collection to determine the frequency of micronuclei $(\mathrm{MN})$.

\section{Exposure Assessment}

The selection of air pollutant parameters is corresponding to six criteria air pollutants in the Air Pollutant Index (API) which has been used since 1989 in Malaysia. An indoor air assessment was conducted in the classrooms of the five selected schools during school hours from 8 a.m. to 1 p.m. $(5 \mathrm{~h})$. The classrooms have a typical design with two doors, louvre windows, ceiling fans for general ventilation, and a surface area of 64.3-67.2 $\mathrm{m}^{2}$. The parameters for the indoor air monitoring included suspended particulate matter $\left(\mathrm{PM}_{1}\right.$, $\mathrm{PM}_{2.5}$, and $\left.\mathrm{PM}_{10}\right)$, gaseous pollutants $\left(\mathrm{NO}_{2}\right.$ and $\left.\mathrm{SO}_{2}\right)$, and physical variables (temperature, relative humidity, and air velocity). The measurements of suspended particulate matter in the classrooms were carried out using a handheld instrument DustTrak ${ }^{\mathrm{TM}}$ DRX Aerosol Monitor 8532 (TSI Incorporated, USA). This lightweight instrument is equipped with a scattering laser photometer and can provide real-time 


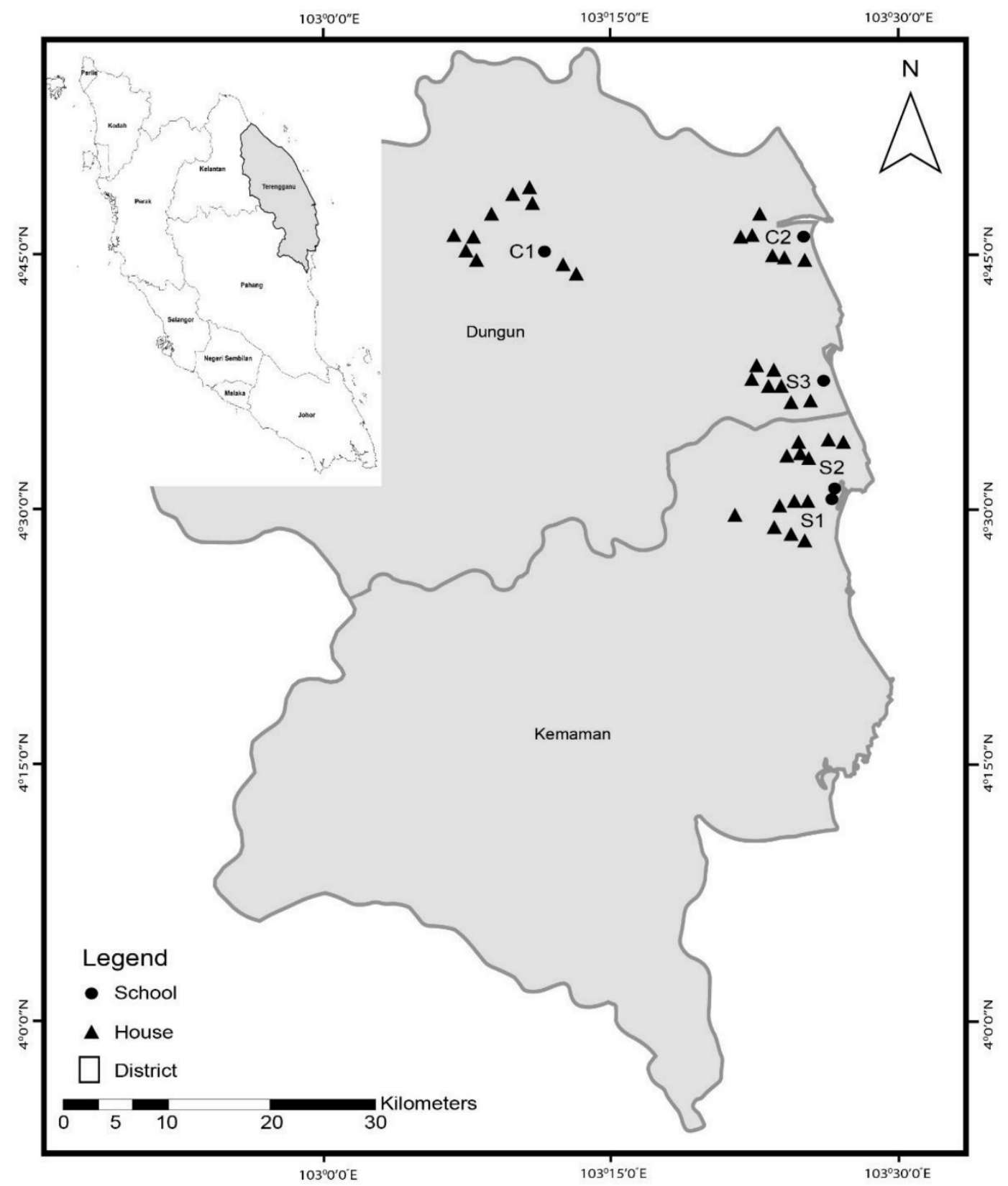

Fig. 1. Terengganu located in the east coast of Peninsular Malaysia (insert). Location of sampling site (primary schools) mark as S1, S2, S3, C1 and C2. Residential's sampling sites are symbolize as triangle, located nearby the schools.

aerosol mass readings. This device is capable of measuring aerosol concentrations of multi-size fraction ranging from 0.001 to $150 \mathrm{mg} \mathrm{m}^{-3}$.

A handheld VelociCalc ${ }^{\circledR}$ Air Velocity Meter 9565 (TSI Incorporated, USA), equipped with multiple sensors, was used to monitor the air velocity, temperature, and relative humidity. This device with $0.01 \mathrm{~m} \mathrm{~s}^{-1}$ resolution is capable of detecting up to $78.7 \mathrm{~m} \mathrm{~s}^{-1}$. The gaseous pollutants were measured using the LaMotte Nitrogen Dioxide and Sulfur Dioxide in Air test kit (LaMotte, USA), in which the air was slowly aspirated into a $10 \mathrm{~mL}$ mixture of absorbing solution at a flow rate of 0.2 and $1.0 \mathrm{~L} \mathrm{~min}^{-1}$ for $\mathrm{NO}_{2}$ and $\mathrm{SO}_{2}$ respectively. The principle of detection is colorimetric, in which the intensity of the resulting color of each gas is compared with the LaMotte reference color chart. The measurements were carried out for about an hour each at three scheduled times during the school hours. All the equipment was placed at the back of the classroom at the height of $0.8 \mathrm{~m}$ from the floor to represent the breathing zone of the seated children. The air monitoring was conducted over 4 consecutive days.

\section{Home Assessments}

Home assessments were conducted to determine the micro-environment exposure of the respondents. Consent and approval were obtained from the guardians of the children prior to the home assessment. It involved 40 children's houses located nearby the exposed schools and 33 homes 
situated nearby the comparative schools. The main assessment involved the collection of $\mathrm{PM}_{10}$ using an Escort ELF Personal Air Sampling Pump (Zefon International, USA) at a flow rate of $1.7 \mathrm{~L} \mathrm{~min}{ }^{-1}$, equipped with a pre-weighed $37 \mathrm{~mm}$ diameter size filter paper. The filter was dried in an oven and then placed in a desiccator for at least $24 \mathrm{~h}$ prior to the measurement. It was then placed for $24 \mathrm{~h}$ (at breathing zone's height) at the location where the respondents spent most of their time when at home, e.g., in the bedroom and living room. The sampled filter was then dried in a desiccator for at least a day before its final weight was taken. The concentration of $\mathrm{PM}_{10}$ was determined gravimetrically by the difference in weight of the filter paper before and after sampling.

\section{Collection of Exfoliated Buccal Mucosa and MN Assay}

The buccal mucosa cells were taken by gently scraping both the inner side of the cheeks with a sterile cytology brush. The brush was then dipped into a microcentrifuge tube containing $0.1 \mathrm{M}$ phosphate buffer solution ( $\mathrm{pH} 7.5)$ and stored in $\mathrm{a}-20^{\circ} \mathrm{C}$ freezer (Holland et al., 2008). Next, the cells were smeared onto a glass slide followed by a fixation process with a cold solution of $1 \%$ glutaraldehyde in $0.1 \mathrm{M}$ phosphate buffer ( $\mathrm{pH} 7.5$ ) for $20 \mathrm{~min}$. The slide was then stained with a Feulgen solution using a modified procedure by Belien et al. (1995) and counterstained with $0.1 \%$ Fast Green for 20 seconds. Finally, the slide was observed under a light microscope at $40 \times$ magnification. The results were then expressed as frequency of $\mathrm{MN}$ in 1000 cells (Fig. 2).

\section{Statistical Analysis}

All the data were analyzed using the Statistical Package for the Social Sciences (SPSS) Version 22.0. A normality test was performed to assess the data distribution among the exposed and comparative groups. The information gathered would then determine the selection of subsequent statistical analysis, i.e., either parametric or non-parametric testing. The analysis comprised univariate, bivariate, and multivariate statistical testing in proving the relationship between air pollutant exposure and the occurrence of respiratory symptoms and micronuclei formation. The univariate analysis comprised descriptive statistics for socio-demographic information, air pollutant concentration, and micronuclei frequency. The bivariate analysis involved mean or median comparison of the studied variables, specifically for continuous data. Meanwhile, categorical data such as respiratory symptoms and homes' distances were assessed through chi-square analysis. In addition, it was performed to evaluate whether the differences in micronuclei frequency have a relationship with air pollutants' concentration. Multiple linear regression was performed to assess the contributing factors of micronuclei frequency among the respondents.

\section{RESULTS AND DISCUSSION}

\section{Socio-demographic}

176 respondents were involved in this study. For the exposed group, 48 (47.5\%) respondents were boys and another $53(52.5 \%)$ were girls. For the comparative group, there were 34 boys $(45.3 \%)$ and 41 girls $(54.7 \%)$. Most of the children lived rather close to the main road, i.e., 37 (38.9\%) for the exposed group and 39 (54.2\%) for the comparative group. Proximity to a road can lead to higher levels of indoor air pollutants in the house due to emissions from the road vehicles being so much closer. A study conducted in Australia found that houses nearby busy roads exhibited both higher indoor and outdoor air pollutant concentrations compared to houses further away from the road (Cheng et al., 2010). Most of the children in the exposed group lived more than $1.5 \mathrm{~km}$ from the industries, i.e., $53(58.9 \%)$ children. Meanwhile, most of the children in the comparative group lived more than $5 \mathrm{~km}$ from the industries, i.e., $53(77.9 \%)$ children.

\section{Air Quality in Indoor Environment: Schools}

The monitored results pertaining to suspended particulate matter $\left(\mathrm{PM}_{1}, \mathrm{PM}_{2.5}\right.$ and $\left.\mathrm{PM}_{10}\right)$, gaseous pollutants $\left(\mathrm{NO}_{2}\right.$, $\mathrm{SO}_{2}$ ) and physical parameters (temperature, relative humidity, air velocity) in the classrooms are tabulated in Table 1 . The classroom of the exposed school S1, which is located less than $5 \mathrm{~km}$ from the industrial zone, recorded the highest $\mathrm{PM}_{1}$ concentration at $43.33 \mu \mathrm{g} \mathrm{m}^{-3}$ as compared to other schools. Meanwhile, the average concentration of $\mathrm{PM}_{2.5}$ and $\mathrm{PM}_{10}$

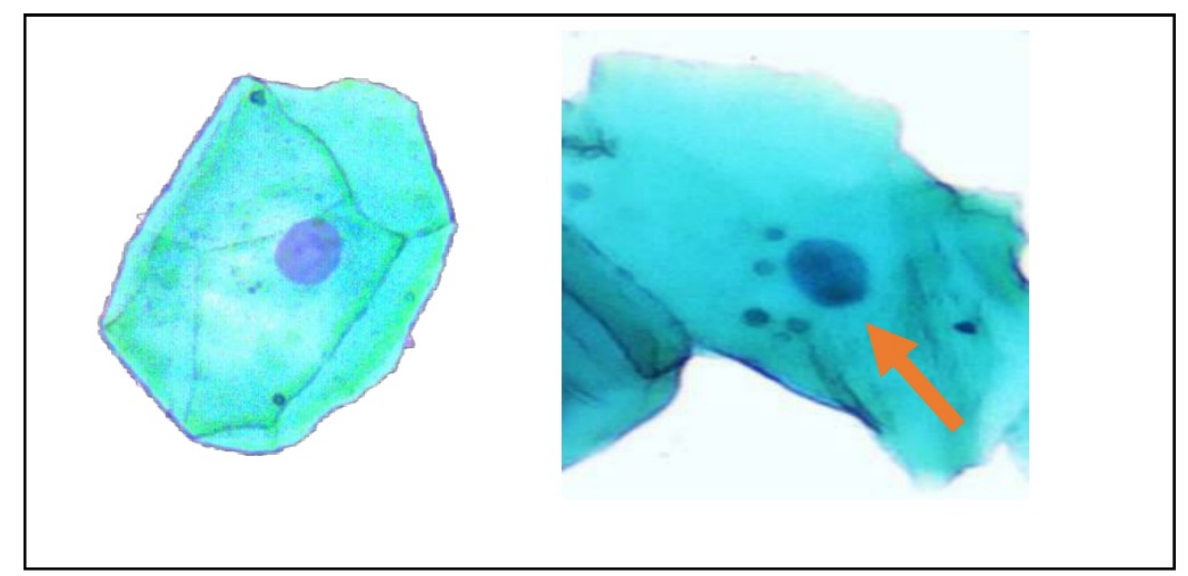

Fig. 2. Buccal epithelial cell with presence of micronucleus under $40 \times$ magnification (arrow indicates of micronucleus). 
Table 1. Summary of indoor air pollutants concentrations in the classrooms.

\begin{tabular}{|c|c|c|c|c|c|c|}
\hline \multirow{2}{*}{ School } & \multirow{2}{*}{ Statistic } & \multicolumn{3}{|c|}{ Exposed School } & \multicolumn{2}{|c|}{ Comparative School } \\
\hline & & S1 & $\mathrm{S} 2$ & S3 & $\mathrm{C} 1$ & $\mathrm{C} 2$ \\
\hline \multirow[t]{3}{*}{$\mathrm{PM}_{1}\left(\mu \mathrm{g} \mathrm{m}^{-3}\right)$} & Min & 25.00 & 16.25 & 20.00 & 14.33 & 14.00 \\
\hline & Max & 120.83 & 140.00 & 191.00 & 106.44 & 80.50 \\
\hline & Avg & 43.30 & 30.75 & 39.25 & 29.33 & 24.75 \\
\hline \multirow[t]{3}{*}{$\mathrm{PM}_{2.5}\left(\mu \mathrm{g} \mathrm{m}^{-3}\right)$} & Min & 25.50 & 16.50 & 20.75 & 14.33 & 14.00 \\
\hline & Max & 121.33 & 152.00 & 202.75 & 113.00 & 81.75 \\
\hline & Avg & 44.83 & 32.00 & 41.00 & 29.67 & 25.50 \\
\hline \multirow[t]{3}{*}{$\mathrm{PM}_{10}\left(\mu \mathrm{g} \mathrm{m}^{-3}\right)$} & Min & 28.00 & 17.25 & 22.75 & 14.67 & 14.75 \\
\hline & Max & 241.67 & 296.00 & 425.25 & 215.00 & 116.75 \\
\hline & Avg & 60.83 & 39.50 & 60.50 & 35.00 & 31.25 \\
\hline \multirow[t]{3}{*}{$\mathrm{NO}_{2}\left(\mu \mathrm{g} \mathrm{m}^{-3}\right)$} & Min & $<0.01$ & $<0.01$ & $<0.01$ & $<0.01$ & $<0.01$ \\
\hline & Max & 87.75 & & & & \\
\hline & Avg & 21.94 & & & & \\
\hline \multirow[t]{3}{*}{$\mathrm{SO}_{2}\left(\mu \mathrm{g} \mathrm{m}^{-3}\right)$} & Min & 130.93 & 78.56 & 340.44 & $<0.01$ & 78.56 \\
\hline & Max & 130.93 & 130.93 & 340.43 & & 78.56 \\
\hline & Avg & 130.93 & 104.75 & 340.43 & & 78.56 \\
\hline \multirow[t]{3}{*}{$\mathrm{T}\left({ }^{\circ} \mathrm{C}\right)$} & Min & 28.00 & 28.50 & 28.94 & 27.50 & 27.80 \\
\hline & Max & 31.20 & 31.40 & 28.94 & 33.00 & 31.80 \\
\hline & Avg & 30.10 & 30.10 & 28.94 & 30.20 & 30.20 \\
\hline \multirow[t]{3}{*}{ RH (\%) } & Min & 66.6 & 71.20 & 77.70 & 58.50 & 65.30 \\
\hline & Max & 72.4 & 81.70 & 77.70 & 84.40 & 81.00 \\
\hline & Avg & 69.4 & 74.80 & 77.70 & 71.60 & 72.20 \\
\hline \multirow[t]{3}{*}{$\mathrm{V}\left(\mathrm{m} \mathrm{s}^{-1}\right)$} & Min & 0.37 & 0.16 & 0.25 & 0.28 & 0.033 \\
\hline & Max & 0.78 & 0.17 & 0.45 & 0.36 & 0.36 \\
\hline & Avg & 0.49 & 0.17 & 0.30 & 0.31 & 0.33 \\
\hline
\end{tabular}

for $\mathrm{S} 1$ were 44.83 and $60.83 \mu \mathrm{g} \mathrm{m}^{-3}$, respectively. High concentrations of fine particles are usually contributed by outdoor infiltration of the pollutants into the indoor space (Almeida et al., 2011). In addition, the outdoor pollutants easily penetrate the indoor environment due to a greater air exchange rate through the larger window area (Yang et al., 2017). A study by Yang et al. (2017) demonstrated the high concentration of indoor particles in the classroom was confidently contributed by the outdoor source, with 0.9217 infiltration coefficient.

Two comparative schools (C1 and C2), located over $20 \mathrm{~km}$ from the industries, recorded the lowest particulate matter concentrations, ranging from 24.75 to $35.00 \mu \mathrm{g} \mathrm{m}^{-3}$ (Table 1). The concentrations in the comparative schools seemed to be relatively lower than the concentration of $\mathrm{PM}_{2.5}$ and $\mathrm{PM}_{10}$ in Northern Iran $\left(\mathrm{PM}_{2.5}: 46.9 \mu \mathrm{g} \mathrm{m}^{-3}\right.$ and $\left.\mathrm{PM}_{10}: 397.2 \mu \mathrm{g} \mathrm{m}^{-3}\right)$ due to seasonal differences (Mohammadyan et al., 2017). Statistical analysis depicted a significant difference of particulate matter concentrations between the exposed and comparative schools. As shown in Table 2, the average concentration of particulate matter was found to be higher than those reported in the previous study (Yang Razali et al., 2015). The mean particulate matter concentrations of those schools in Bandar Baru Bangi and Putrajaya, Malaysia, recorded during school hours were 16,18 , and $31 \mu \mathrm{g} \mathrm{m}^{-3}$ for $\mathrm{PM}_{1}, \mathrm{PM}_{2.5}$, and $\mathrm{PM}_{10}$, respectively.

Furthermore, indoor gas measurement demonstrated the highest $\mathrm{NO}_{2}$ concentration at the exposed school $\mathrm{S} 1$ $\left(21.94 \mu \mathrm{g} \mathrm{m}^{-3}\right)$, while the other schools exhibited low $\mathrm{NO}_{2}$ value and under the limit of detection. The indoor $\mathrm{NO}_{2}$ concentration recorded in this study did not exceed the recommended value by the WHO Guidelines for Indoor Air Quality of $200 \mu \mathrm{g} \mathrm{m}^{-3}$ and the Malaysian New Ambient Air Quality Standard of $320 \mu \mathrm{g} \mathrm{m}^{-3}$ for 1-h averaging time (DOE, 2020; WHO, 2006). Similarly, the $\mathrm{NO}_{2}$ concentration in this study achieved the excellent criteria of the Hong Kong IAQ Objectives for Offices and Public Places, as the recommended $\mathrm{NO}_{2}$ concentration is $150 \mu \mathrm{g} \mathrm{m} \mathrm{m}^{-3}$ (EMSD, 2003). In the absence of indoor sources, the $\mathrm{NO}_{2}$ concentration found in this study indicated the infiltration of outdoor sources through windows and door openings (Wichmann et al., 2010). Moreover, the location of S1 is adjacent to a high school and it is close to the main road, which also justified the high $\mathrm{NO}_{2}$ concentration in the indoor classroom (Demirel et al., 2014). In a recent study, a similar concentration of $\mathrm{NO}_{2}$ was obtained $\left(25 \mu \mathrm{g} \mathrm{m}^{-3}\right)$ from the sampling site at the closest roadside to the cleaner industrial city, which was detected on working days (Azhari et al., 2018). The highest indoor concentration of $\mathrm{SO}_{2}$ was recorded at S3 $\left(340 \mu \mathrm{g} \mathrm{m}^{-3}\right)$, followed by S1 $\left(130.93 \mu \mathrm{g} \mathrm{m}^{-3}\right), \mathrm{S} 2\left(104.75 \mu \mathrm{g} \mathrm{m}^{-3}\right)$, and C2 $\left(78.56 \mu \mathrm{g} \mathrm{m}^{-3}\right)$. Generally, the $\mathrm{SO}_{2}$ concentrations in this study, especially at the exposed schools, were lower than the concentration recorded in Suhaimi et al. (2015), with a median concentration of $332.57 \mu \mathrm{g} \mathrm{m}^{-3}$, as the pollutant source from that study was mainly generated by multisource industrial combustion such as bitumen and steel manufacturing. The proximity to the industry strongly explained the high concentration of colorless $\mathrm{SO}_{2}$ at the exposed area was predominantly associated with industrial emission (Ielpo et al., 2019). 
Table 2. Comparison of the indoor air pollutants concentrations between the schools of the exposed and comparative schools.

\begin{tabular}{lllllll}
\hline \multirow{2}{*}{ Variable } & \multicolumn{2}{c}{ Exposed schools } & & \multicolumn{2}{c}{ Comparative schools } \\
\cline { 2 - 3 } \cline { 5 - 6 } & Mean \pm SD & Median $(\mathrm{IQR})$ & & Mean \pm SD & Median $(\mathrm{IQR})$ & \\
\hline $\mathrm{PM}_{1}\left(\mu \mathrm{g} \mathrm{m}^{-3}\right)$ & $46.90 \pm 15.64$ & $40.00(28.00)$ & & $28.50 \pm 4.47$ & $26.00(7.75)$ & $0.006^{*}$ \\
$\mathrm{PM}_{2.5}\left(\mu \mathrm{g} \mathrm{m}^{-3}\right)$ & $48.82 \pm 15.89$ & $41.00(28.00)$ & & $29.75 \pm 5.36$ & $27(6.75)$ & $0.005^{*}$ \\
$\mathrm{PM}_{10}\left(\mu \mathrm{g} \mathrm{m}^{-3}\right)$ & $69.73 \pm 19.72$ & $77.00(35.00)$ & & $36.00 \pm 6.44$ & $34(8.50)$ & $<0.001^{* *}$ \\
$\mathrm{NO}_{2}\left(\mu \mathrm{g} \mathrm{m}^{-3}\right)$ & $31.91 \pm 44.27$ & $0.00(0.14)$ & & $<0.01$ & $<0.01$ & 0.075 \\
$\mathrm{SO}_{2}\left(\mu \mathrm{g} \mathrm{m}^{-3}\right)$ & $197.59 \pm 98.93$ & $130.93(209.5)$ & & $72.01 \pm 49.98$ & $78.56(98.20)$ & $0.002^{*}$ \\
$\mathrm{~T}\left({ }^{\circ} \mathrm{C}\right)$ & $28.88 \pm 0.86$ & $28.91(0.91)$ & & $29.06 \pm 0.98$ & $29.15(1.66)$ & 0.534 \\
$\mathrm{RH}(\%)$ & $76.83 \pm 3.43$ & $77.70(3.43)$ & & $75.69 \pm 5.89$ & $75.28(9.51)$ & 0.484 \\
$\mathrm{~V}\left(\mathrm{~m} \mathrm{~s}^{-1}\right)$ & $0.32 \pm 0.19$ & $0.26(0.26)$ & & $0.54 \pm 0.40$ & $0.33(0.61)$ & 0.163 \\
\hline
\end{tabular}

$N=20$, Mann-Whitney U test, $*$ significant at $p<0.05, * *$ significant at $p<0.00$.

The physical parameters of the indoor air quality for each school are depicted in Table 1. The indoor temperature indicated a similar value range value from 27.50 to $33.00^{\circ} \mathrm{C}$, while the indoor relative humidity recorded readings between $58.50 \%$ and $84.40 \%$ during the school hour. Both parameters statistically appear to indicate no significant differences between the two groups; however, the relative humidity and temperature in the classrooms generally exceeded the maximum comfort range value of temperature $\left(23-26^{\circ} \mathrm{C}\right)$ and relative humidity $(40-70 \%)$ as recommended in the DOSH guidelines (DOSH, 2010). In addition, the values also did not comply with the international standard, American Society of Heating, Refrigerating and Air-Conditioning Engineers (ASHRAE) Standard 55, as the recommended comfortability's temperature in summer ranges from 22.8 to $26.1^{\circ} \mathrm{C}$ (ASHRAE, 2013). Meanwhile, the indoor relative humidity levels should be maintained between $30 \%$ and $65 \%$ for optimum comfort as suggested by ASHRAE. The measured indoor air velocity for both exposed and comparative schools met the recommended air velocity in the DOSH guidelines, which is $0.15-0.50 \mathrm{~m} \mathrm{~s}^{-1}$.

\section{Home Assessments}

The concentrations of the air pollutants observed in the homes $(n=73)$ of the children in the exposed and comparative groups are shown in Table 3 . The mean concentration of the pollutants was observed to be higher for the exposed group, $108.39 \pm 94.11 \mu \mathrm{g} \mathrm{m}^{-3}$, than the comparative group, $46.15 \pm$ $41.29 \mu \mathrm{g} \mathrm{m}^{-3}$. The $\mathrm{PM}_{10}$ concentrations, however, were still within the Malaysian Ambient Air Quality Standards $\left(150 \mu \mathrm{g} \mathrm{m}^{-3}\right.$ for $\left.24 \mathrm{~h}\right)$. The higher levels of pollutants observed in the homes of the exposed group could indicate high penetration of outdoor air pollutants into their homes through the windows and doors, which were normally left open during the daytime for better ventilation. The result of
Mann-Whitney $U$ disclosed a significant difference between the two groups, with the exposed area recording higher indoor $\mathrm{PM}_{10}$ concentration than the homes in comparative area. Their values, however, were lower than those observed in another study by Suhaimi et al. (2015). In that study, the location was near to heavy industries such as metal processing plants, an oil refinery and a gas processing plant. Vanker et al. (2015) demonstrated the daily $\mathrm{PM}_{10}$ measured in the 592 homes in a peri-urban area of Cape Town, South Africa, was 33.1 (interquartile range, IQR 13-62.2) $\mu \mathrm{g} \mathrm{m}^{-3}$, which is lower than the $\mathrm{PM}_{10}$ measured in this study. About 4 homes in this study had low particles concentrations of less than $46.15 \mu \mathrm{g} \mathrm{m}^{-3}$, and this might be closely related to frequent cleaning as it may reduce dust accumulation on the floor and furniture surface.

The gas pollutant measurement depicted significant differences of $\mathrm{NO}_{2}$ and $\mathrm{SO}_{2}$ concentration between the residences in exposed and comparative areas. The $\mathrm{NO}_{2}$ concentration of the exposed area were highly detected in those homes located in the vicinity of main road, which is less than $100 \mathrm{~m}$. This is corresponded to anthropogenic source of $\mathrm{NO}_{2}$ which mainly originated from vehicle combustion and secondarily from industrial emission (Ielpo et al., 2019). However, the indoor $\mathrm{NO}_{2}$ concentration in this study $(20.78$ $\pm 37.81 \mu \mathrm{g} \mathrm{m}^{-3}$ ) were found to be extremely lower than in the study by Suhaimi et al. (2015) where the obtained value was between 58.29 and $165.48 \mu \mathrm{g} \mathrm{m}^{-3}$. This could be due to the active emission of by-products of high-temperature combustion from the nearby industry in the Kemaman industrial area. Nevertheless, $\mathrm{SO}_{2}$ concentration in the residences of the exposed area were found to be higher than concentration measured in previous study (Suhaimi et al., 2015). The Mann-Whitney $U$ analysis disclosed a significantly higher $\mathrm{SO}_{2}$ concentration in the exposed area $\left(141.96 \pm 59.85 \mu \mathrm{g} \mathrm{m}^{-3}\right)$ as compared to those in the comparative area $\left(130.93 \mu \mathrm{g} \mathrm{m}^{-3}\right)$.

Table 3. Comparison of indoor air pollutants concentrations between the homes of the respondents in the exposed and comparative groups.

\begin{tabular}{|c|c|c|c|c|c|c|}
\hline \multirow{2}{*}{ Variable } & \multicolumn{2}{|c|}{ Exposed Area $(N=40)$} & \multicolumn{2}{|c|}{ Comparative Area $(N=33)$} & \multirow{2}{*}{ z-value } & \multirow{2}{*}{$p$-value } \\
\hline & Mean \pm SD & Median (IQR) & Mean \pm SD & Median (IQR) & & \\
\hline $\mathrm{PM}_{10}\left(\mu \mathrm{g} \mathrm{m}^{-3}\right)$ & $108.39 \pm 94.11$ & $84.22(60.79)$ & $46.15 \pm 41.29$ & $42.22(64.13)$ & -2.6 & $0.007^{*}$ \\
\hline $\mathrm{NO}_{2}\left(\mu \mathrm{g} \mathrm{m}^{-3}\right)$ & $20.78 \pm 37.81$ & $0.00(21.94)$ & $<0.01$ & $<0.01$ & -2.930 & $0.003 *$ \\
\hline $\mathrm{SO}_{2}\left(\mu \mathrm{g} \mathrm{m}^{-3}\right)$ & $141.96 \pm 59.85$ & $130.93(0.00)$ & $6.89 \pm 30.04$ & $0.00(0.00)$ & -5.233 & $<0.001 * *$ \\
\hline
\end{tabular}

$N=73$, Man Whitney U test, * Significant at $p<0.05, * *$ Significant at $p<0.001$. 
This study also considered other variables in their homes that might have possible effects on the indoor air quality. This part was assessed in the questionnaires. These variables included family members who smoke; types of materials for the walls, floors etc.; fuels for cooking; whether windows were opened during cooking; and whether there were carpets in the homes. Generally, all the possible indoor air pollutants confounders did not exhibit any significant difference between the exposed and comparative groups.

\section{Time Series for Particulate Matter Concentrations}

The results of the 5-h sampling for particulate matter in the five different schools are shown in Fig. 3. Several observations could be made regarding the particulate trend

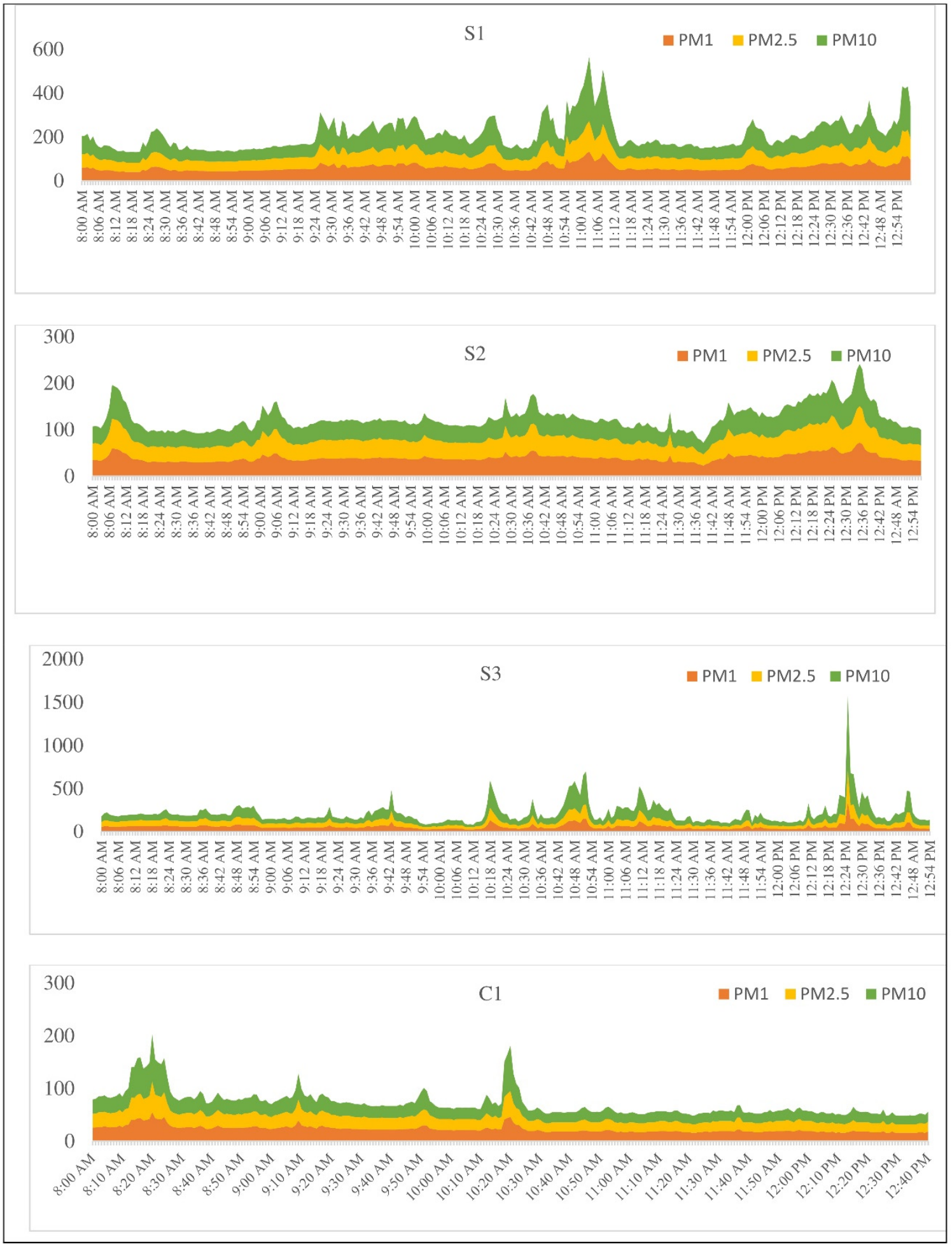

Fig. 3. 5 h' time series on indoor $\mathrm{PM}_{1}, \mathrm{PM}_{2.5}$ and $\mathrm{PM}_{10}$ in classroom of 5 different schools. 


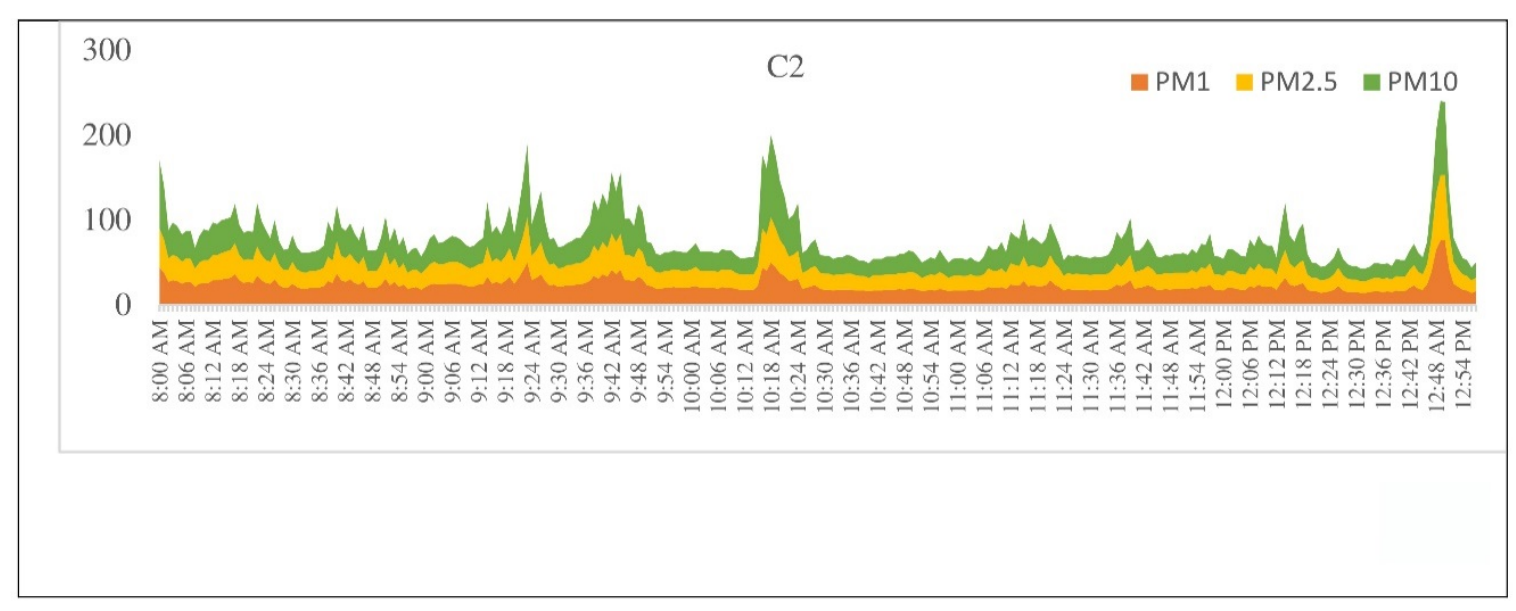

Fig. 3. (continued).

during the sampling period. Relatively high concentrations were observed during the first 15-20 min when the children entered the classrooms, possibly due to a lot of movements to get to their seats and to get their books from the bookshelves, as well as the daily routine of sweeping the floor clean. The concentration of particulate matter was relatively low prior to recess time due to lower levels of physical activities as the children were more engrossed in their schoolwork. This finding is consistent to those observed by Yang et al. (2015) in that higher pollutants levels in the classrooms were contributed by the number of occupants inside and their activities, such as walking and running, which caused the particulate matter to be churned up into the air (Yang et al., 2015). High levels of particulate were also observed during the break time due to the re-suspension of the particles caused by the movement of the children. This is consistent with the trend observed in previous studies (Ismail et al., 2010; Yang Razali et al., 2015). In addition, the active movement of the children also tended to increase the air turbulence, leading to high uplifting of indoor particles (Madureira et al., 2015).

\section{Comparison of Reported Respiratory Health Symptoms}

The prevalence of respiratory health symptoms (cough, chest tightness, wheezing, and phlegm) among the respondents $(n=176)$ in the exposed and comparative groups was assessed using a set of standardized questionnaires. A significant difference in the prevalence of cough was observed when comparing the two groups, with prevalence ratio 2.52 (95\% confidence interval [CI] 1.13-1.56). The prevalence ratio for chest tightness and phlegm were 1.80 (95\% CI 0.53-6.07) and 1.15 (95\% CI 0.45-2.98), respectively. Children in the exposed group with higher exposure to air pollutants were three times more likely to develop respiratory symptoms than those children in the comparative area, as parallel with an earlier study by Suhaimi et al. (2015). It was suggested that their proximity to the heavy industries could have worsened their respiratory health (de Moraes et al., 2010; Rusconi et al., 2011; Sopian et al., 2016). A study by Ayuni et al. (2014) also found significantly high respiratory health symptoms among children living in proximity to a petrochemical industry with the prevalence ratio for cough, phlegm, chest tightness and wheezing being 5.09 (95\% CI 2.23-11.65), 9.66 (95\% CI 2.10-44.46), 9.08 (95\% CI 1.0975.0) and 9.07 (95\% CI 1.89-25.2), respectively. In addition, the incremental increase in air pollutant levels in the air have also been convincingly associated with the high occurrence of respiratory illness among non-asthmatic children, especially for 7-day average exposures to $\mathrm{PM}_{2.5}, \mathrm{PM}_{10}, \mathrm{O}_{3}, \mathrm{NO}_{2}$, and $\mathrm{SO}_{2}$ (Prieto-parra et al., 2017). A recent study by Luong et al. (2017) also observed an association between elevated levels of particulate matter and the occurrence of respiratory illness among children resulting in incremental respiratory hospital admission. One can thus infer that exposure to high concentrations of air pollutants from traffic or industrial emissions could worsen the respiratory health among children.

\section{Micronucleus Assay}

A micronucleus assay was carried out on 91 children who fulfilled the inclusive criteria. Children in the exposed group had an average micronuclei frequency of $5.02 \pm 3.43$ per 1000 cells, while those in the comparative group had $2.00 \pm$ 1.56. The Mann-Whitney $U$ analysis found a significant difference in the median of the exposed group $(p<0.001)$. The results showed that the exposed group had a micronuclei frequency two times higher than a normal baseline value (a mean of $2.32 \pm 0.28$ per 1000 cells) of a similar age group as indicated in Gajski et al. (2013). Similar findings were also observed in 74 children aged 5-15 years old in a highly polluted province in Poland, with a mean micronuclei frequency of $6.56 \pm 5.00 \mathrm{MN}$ per 1000 cells (MielzynskaSvach et al., 2014). High exposure to biomass burning had also induced a significant increase in micronuclei frequency among a similar age group of children with a mean of 15.7 $\pm 8.3 \mathrm{MN}$ per 1000 cells (Sisenando et al., 2012). On the other hand, the comparative group had a relatively low micronuclei frequency, similar to the normal value of healthy children in a clean town in Brazil, i.e., $3 \pm 4.1$ per 1000 cells (Silva da Silva et al., 2015).

To date, there is no specific cut-off point of micronuclei frequency that can be used as a reference to justify the genotoxicity at the microcellular level. As such, the 
genotoxicity of buccal mucosa (micronuclei frequency) was categorized based on the median value of frequency measured, which was 3 . The values that were higher than or equal to the median $(\geq 3)$ were categorized as likely present, while the values lower than the median $(<3)$ were categorized as unlikely present (Table 4$)$. The chi-square analysis indicated that there was a significant positive correlation between indoor air pollutants and micronuclei frequency. This finding supported the results of other studies regarding exposure to high particulate matter and high micronuclei frequency counted on buccal epithelial cells (Sisenando et al., 2012; Ceretti et al., 2014; Tan et al., 2017). One could thus infer that prolonged exposure to high levels of air pollutants could induce cumulative chromosomal damages and increase the risk of cancer among children living in the vicinity of polluting industries.

Multiple linear regression was performed to assess the contributing factors of micronuclei frequency among the respondents. The model contained five main indoor air pollutants $\left(\mathrm{PM}_{1}, \mathrm{PM}_{2.5}, \mathrm{PM}_{10}, \mathrm{SO}_{2}\right.$, and $\left.\mathrm{NO}_{2}\right)$ that were monitored in this study. Statistically, there was an association between the indoor air pollutants $\left(\mathrm{PM}_{10}, \mathrm{SO}_{2}\right.$, and $\left.\mathrm{NO}_{2}\right)$ and micronuclei frequency. Based on regression analysis, we found that $\mathrm{NO}_{2}$ was the most significant air pollutant predictor to induce micronuclei formation with the adjusted odds ratio of $6.82(95 \%$ CI $35.72-105.18)$ and $R^{2}$ value of 0.498 , after controlling all possible confounders such as distance of the homes from the roads and industries, as well as indoor exposure from smoking and carpets. It has been suggested that $\mathrm{NO}_{2}$ caused induction of micronuclei frequency or permanent DNA impairment on human nasal epithelial cell at $0.2 \mathrm{mg} \mathrm{m}^{-3}$ after being exposed for $3 \mathrm{~h}$ (Koehler et al., 2011). The high exposure to air pollutants, such as $\mathrm{PM}_{10}$ and $\mathrm{SO}_{2}$, had likely contributed to the high formation of micronuclei among the respondents, with adjusted odds ratio of 2.31 (95\% CI $0.06-0.73)$ and 4.03 (95\% CI 9.70-17.67), respectively.

Synergistic and additive effects of other air pollutants such as volatile organic compounds (VOCs), polyaromatic hydrocarbon (PAHs), and heavy metals emitted from the industry should be considered in this study. Inhalation of metal can interfere with catalytic site of DNA synthesis and may result in disrepair of DNA strand break. On the other hand, inhalation of PAHs can inhibit DNA methylation and induce DNA adduct (e.g., benzo[a]pyrene diol epoxide).
The failure of the cell to repair the DNA strand break, lesion and adduct can lead to induction of micronuclei (Fenech et al., 2016). This could be one limitation of the present study as the measurement of other pollutants were not investigated. Apart from that, the smaller sample size in this study may also limit the findings. Future studies with larger sample size, and additional application of genotoxic biomarker are warranted to authorize the findings.

\section{CONCLUSION}

This study reveals significant differences in the concentrations of indoor air pollutants (especially $\mathrm{PM}_{1}$, $\mathrm{PM}_{2.5}, \mathrm{PM}_{10}$, and $\mathrm{SO}_{2}$ ) between schools in the vicinity of an industrial park (the schools for the exposed group) and those situated farther away (the schools for the comparative group). The pollutant levels were significantly higher at former, particularly for $\mathrm{PM}_{10}\left(69.73 \pm 19.72 \mathrm{vs.} 36.00 \pm 6.44 \mu \mathrm{g} \mathrm{m}^{-3} ; p\right.$ $<0.001)$. Additionally, the mean $\mathrm{PM}_{10}$ concentrations at the homes of the exposed and comparative groups were 108.39 \pm 94.11 and $46.15 \pm 41.29 \mu \mathrm{g} \mathrm{m}^{-3}$, respectively. Poor air quality conditions increased the average micronucleus frequency among the children $(5.02 \pm 3.43 \mathrm{MN}$ per 1000 cells for the exposed group vs. $2.00 \pm 1.56 \mathrm{MN}$ per 1000 cells for the comparative group), indicating a higher genotoxic risk, as well as the prevalence of respiratory symptoms (children in the exposed group were three times more likely to develop symptoms, especially coughing).

These results, after controlling for confounding factors (e.g., demographic, socio-economic, and lifestyle factors, and exposure to tobacco smoke), strongly suggest that exposure to industrial air pollutants $\left(\mathrm{NO}_{2}, \mathrm{SO}_{2}\right.$, and $\left.\mathrm{PM}_{10}\right)$ increases the risk of chromosomal damage for children residing in proximity to an industrial area. Specifically, statistical analysis reveals a significant association between micronucleus frequency and indoor concentrations of $\mathrm{NO}_{2}$ (adjusted odds ratio of $6.82 ; 35.72-105.18,95 \% \mathrm{CI}$ ), $\mathrm{SO}_{2}$ (adjusted odds ratio of $4.03 ; 9.70-17.67,95 \% \mathrm{CI}$ ), and $\mathrm{PM}_{10}$ (adjusted odds ratio of $2.31 ; 0.06-0.73,95 \%$ CI). Furthermore, the pollutants we measured (both gaseous and solid) are proxy indicators of pollution in the area, as demonstrated by ambient data from continuous air quality monitoring stations and previous local studies.

This study fills the knowledge gap in epidemiological studies regarding the relationship between industrial air

Table 4. Association of school indoor air pollutants with frequency of MN among primary school children

\begin{tabular}{|c|c|c|c|c|c|c|}
\hline Variable & $\begin{array}{l}\text { Likely present } \\
(\mathrm{MN} \geq 3) \text { Total }(\%)\end{array}$ & $\begin{array}{l}\text { Unlikely present } \\
(\mathrm{MN}<3) \text { Total }(\%)\end{array}$ & $\chi^{2}$ & p-value & PR & $95 \% \mathrm{CI}$ \\
\hline 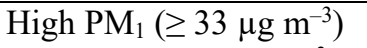 & $33(78.6)$ & $9(21.4)$ & \multirow{2}{*}{17.588} & \multirow{2}{*}{$<0.001^{*}$} & \multirow{2}{*}{2.265} & \multirow{2}{*}{$1.495-3.431$} \\
\hline Low $\mathrm{PM}_{1}\left(<33 \mu \mathrm{g} \mathrm{m}^{-3}\right)$ & $17(34.7)$ & $32(65.3)$ & & & & \\
\hline $\operatorname{High} \mathrm{PM}_{2.5}\left(\geq 36 \mu \mathrm{g} \mathrm{m}^{-3}\right)$ & $36(73.5)$ & $13(26.5)$ & \multirow{2}{*}{14.716} & \multirow{2}{*}{$<0.001 *$} & \multirow{2}{*}{2.204} & \multirow{2}{*}{$1.392-3.490$} \\
\hline Low $\mathrm{PM}_{2.5}\left(<36 \mu \mathrm{g} \mathrm{m}^{-3}\right)$ & $14(33.3)$ & $28(66.7)$ & & & & \\
\hline $\operatorname{High} \mathrm{PM}_{10}\left(\geq 51 \mu \mathrm{g} \mathrm{m}^{-3}\right)$ & $38(74.5)$ & $13(25.5)$ & \multirow{2}{*}{17.940} & \multirow{2}{*}{$<0.001^{*}$} & \multirow{2}{*}{2.484} & \multirow{2}{*}{$1.507-4.094$} \\
\hline Low $\mathrm{PM}_{10}\left(<51 \mu \mathrm{g} \mathrm{m}^{-3}\right)$ & $12(30.0)$ & $28(70.0)$ & & & & \\
\hline $\operatorname{High} \mathrm{SO}_{2}\left(\geq 130 \mu \mathrm{g} \mathrm{m}^{-3}\right)$ & $43(68.3)$ & $20(31.7)$ & \multirow{2}{*}{14.650} & \multirow{2}{*}{$<0.001 *$} & \multirow{2}{*}{2.730} & \multirow{2}{*}{$1.406-5.300$} \\
\hline Low $\mathrm{SO}_{2}\left(<130 \mu \mathrm{g} \mathrm{m}^{-3}\right)$ & $7(25.0)$ & $21(75.0)$ & & & & \\
\hline
\end{tabular}

$N=91$, Chi-square test, $*$ Significant at $p<0.001$, Significant PR at 95\% CI $>1$. 
pollutants and genotoxicity among children in South East Asia. However, certain limitations must be noted, including the small number of respondents and our inability to investigate personal air pollutant exposure. Moreover, toxic pollutants that were not addressed in this study, such as PAHs and benzene, potentially influence the formation of micronuclei in children through additive and synergistic effects. Future research should quantify the carcinogenic air pollutants in the study area in order to evaluate the combined effects of exposure to industrial air pollutants on children. A comprehensive air quality assessment can be achieved by actively sampling a larger air volume, increasing the sampling duration (up to $24 \mathrm{~h}$ ), determining the particulate matter composition (i.e., identifying heavy metals and inorganic and organic compounds), measuring toxic gases, and conducting source apportionment.

\section{ACKNOWLEDGEMENT}

The authors acknowledge the great support and assistance from the Environmental Health Lab, Faculty of Medicine and Health Sciences, Universiti Putra Malaysia and Laboratory 2146, Faculty of Science and Technology, Universiti Kebangsaan Malaysia. This study was funded by Universiti Putra Malaysia (project code: GP-IPS/2016/9504000).

\section{REFERENCES}

Agency for Toxic Substances and Disease Registry (ATSDR) (1998). Toxicological profile for sulfur dioxide. U.S. Department of Health and Human Services, Public Health Service, Atlanta, USA.

Almeida, S.P.D., Casimiro, E. and Calheiros, J. (2011). Short-term association between exposure to ozone and mortality in Oporto, Portugal. Environ. Res. 111: 406410.

American Society of Heating and Air-Conditioning Engineers (ASHRAE) (2013). Thermal environment conditions for human occupancy. American Society of Heating, Refrigerating and Air Conditioning Engineers, Atlanta, USA.

Ayuni, N.A., Juliana, J. and Ibrahim, M.H. (2014). Exposure to $\mathrm{PM}_{10}$ and $\mathrm{NO}_{2}$ and association with respiratory health among primary school children living near petrochemical industry area at Kertih, Terengganu. J. Med. Bioeng. 3: 282-287.

Azhari, A., Talib, M. and Fariz, A. (2018). Road traffic as an air pollutant contributor within an industrial park environment. Atmos. Pollut. Res. 9: 680-687.

Beliën, J.A.M., Copper, M.P., Braakhuis, B.J.M., Snow, G.B. and Baak, J.P.A. (1995). Standardization of counting micronuclei: Definition of a protocol to measure genotoxic damage in human exfoliated cells. Carcinogenesis 16: 2395-2400.

Branco, P.T.B.S., Martins, F.G. and Sousa, S.I.V. (2014). The microenvironmental modelling approach to assess children's exposure to air pollution -A review. Environ. Res. 135: 317-332.

Ceretti, E., Feretti, D., Viola, G.C.V., Zerbini, I., Limina,
R.M., Zani, C., Capelli, M., Lamera, R., Donato, F. and Gelatti, U. (2014). DNA damage in buccal mucosa cells of pre-school children exposed to high levels of urban air pollutants. PLoS One 9: e96524.

Cheng, M., Galbally, I., Gillett, R., Keywood, M., Lawson, S., Molloy, S. and Powell, J. (2010). Indoor air project Part 1: Main report indoor air in typical Australian dwellings. A report to the Air Quality Section, Environment Standards Branch, Department of the Environment, Water, Heritage and the Arts. Commonwealth of Australia, Australia.

de Moraes, A.C.L., Ignotti, E., Netto, P.A., Jacobson, L., Castro, H. and Hacon, S. (2010). Wheezing in children and adolescents living next to a petrochemical plant in Rio Grande do Norte, Brazil. J. Pediatr. 86: 337-344.

de Oliveira Galvão, M.F., de Queiroz, J.D.F., Duarte, E. de S.F., Hoelzemann, J.J., de André, P.A., Saldiva, P.H.N., Menezes Filho, J.A. and Batistuzzo de Medeiros, S.R. (2017). Characterization of the particulate matter and relationship between buccal micronucleus and urinary 1hydroxypyrene levels among cashew nut roasting workers. Environ. Pollut. 220: 659-671.

Demirel, G., Özden, Ö., Dö, T. and Gaga, E.O. (2014). Personal exposure of primary school children to BTEX, $\mathrm{NO}_{2}$ and ozone in Eskişehir, Turkey: Relationship with indoor/outdoor concentrations and risk assessment. Sci. Total Environ. 474: 537-548.

Department of Environment (DOE) (2020). New Malaysia Ambient Air Quality Standard. Department of Environment, Malaysia.

Department of Occupational Safety and Health (DOSH) (2010). Industry code of practice on indoor air quality Malaysia. Department of Occupational Safety and Health, Ministry of Human Resources, Malaysia.

Electrical and Mechanical Services Department (EMSD) (2003). Guidance notes for the management of indoor air quality in offices and public places. Hong Kong. Electrical and Mechanical Services Department, The Government of the Hong Kong Special Administrative Region, Indoor Air Quality Management Group.

Esposito, S., Tenconi, R., Lelii, M., Preti, V., Nazzari, E., Consolo, S. and Patria, M.F. (2014). Possible molecular mechanisms linking air pollution and asthma in children. BMC Pulm. Med. 14: 1-8.

Fenech, M. (2000). The in vitro micronucleus test. Mutat. Res. Fundam. Mol. Mech. Mutagen. 455: 81-95.

Fenech, M., Knasmueller., S., Bolognesi, C., Bonassi, S., Holland N., Migliore, L., Palitti, F., Natarajan, A.T. and Kirsch-Voldersh, M. (2016). Molecular mechanisms by which in vivo exposure to exogenous chemical genotoxic agents can lead to micronucleus formation in lymphocytes in vivo and ex vivo in humans. Mutat. Res. 770: 12-25.

Gajski, G., Geri, M., Orescanin, V. and Garaj-vrhovac, V. (2013). Cytogenetic status of healthy children assessed with the alkaline comet assay and the cytokinesis-block micronucleus cytome assay. Mutat. Res. Genet. Toxicol. Environ. Mutagen. 750: 55-62.

Godoi, R.H.M., Godoi, A.F.L., Gonçalves Junior, S.J., Paralovo, S.L., Borillo, G.C., Gonçalves Gregório Barbosa, 
C., Arantes, M.G., Charello, R.C., Rosário Filho, N.A., Grassi, M.T., Yamamoto, C.I., Potgieter-Vermaak, S., Rotondo, G.G., De Wael, K. and van Grieken, R. (2013). Healthy environment-Indoor Air Quality of Brazilian Elementary Schools nearby Petrochemical Industry. Sci. Total Environ. 463-464: 639-646.

Han, M., Guo, Z., Li, G. and Sang, N. (2013). Nitrogen dioxide inhalation induces genotoxicity in rats. Chemosphere 90: 2737-2742.

Holland, N., Bolognesi, C., Kirsch-Volders, M., Bonassi, S., Zeiger, E., Knasmueller, S. and Fenech, M. (2008). The micronucleus assay in human buccal cells as a tool for biomonitoring DNA damage: The HUMN project perspective on current status and knowledge gaps. Mutat. Res. 659: 93-108.

Ielpo, P., Mangia, C., Marra, G.P., Comite, V., Rizza, U., Uricchio, V.F. and Fermo, P. (2019). Outdoor spatial distribution and indoor levels of $\mathrm{NO}_{2}$ and $\mathrm{SO}_{2}$ in a high environmental risk site of the South Italy. Sci. Total Environ. 648: 787-797.

Ismail, M., Mohd Sofian, N.Z. and Abdullah, A.M. (2010). Indoor air quality in selected samples of primary schools in Kuala Terengganu, Malaysia. Environ. Asia 3: 103108.

Jalaludin, J., Syed Noh, S.N., Suhaimi, N.F. and Md Akim, A. (2014). Tumor necrosis factor-alpha as biomarkers of exposure to indoor pollutants among primary school children in Klang Valley. Am. J. Appl. Sci. 11: 1616-1630.

Juliana, J., Dayang, A.A., Jamal, H.H., Zailina, H. and Bilkis, A.Z. (2001). The influence of indoor pollutant source on respiratory diseases and lung function among children in Hulu Langat District: A preliminary study. Pub Health J. 2: 51-56.

Koehler, C., Ginzkey, G., Friehs, S., Hackenberg, S., Froelich, K., Scherzed, A., Burghartz, M., Kessler, M. and Kleinsasser, N. (2011). Ex vivo toxicity of nitrogen dioxide in human nasal epithelium at the WHO defined 1h limit value. Toxicol. Lett. 207: 89-95.

Korten, I., Ramsey, K. and Latzin, P. (2017). Air pollution during pregnancy and lung development in the child. Paediatr. Respir. Rev. 21: 38-46.

Liu, C., Chen, C.C., Wu, T.N. and Yang, C.Y. (2008). Association of brain cancer with residential exposure to petrochemical air pollution in Taiwan. J. Toxicol. Environ. Health Part A 71: 310-314.

Loyo-Berríos, N.I., Irizarry, R., Hennessey, J.G., Tao, X.G. and Matanoski, G. (2007). Air pollution sources and childhood asthma attacks in Cataño, Puerto Rico. Am. J. Epidemiol. 165: 927-935.

Luong, L.M.T., Phung, D., Sly, P.D., Morawska, L. and Thai, P.K. (2017). The association between particulate air pollution and respiratory admissions among young children in Hanoi, Vietnam. Sci. Total Environ. 578: 249255.

Lwanga, S. and Lemeshow, S. (1991). Sample size determination in health studies: A practical manual. World Health Organization, Geneva.

Madureira, J., Paciencia, I., Rufo, J., Ramos, E., Barros, H., Teixeira, J. and de Oliveira Fernandes, E. (2015). Indoor air quality in schools and its relationship with children's respiratory symptoms. Atmos. Environ. 118: 145-156.

Mergener, M., Rhoden, C.R. and Amantéa, S.L. (2014). Nuclear abnormalities in cells from nasal epithelium: a promising assay to evaluate DNA damage related to air pollution in infants. J. Pediatr. 90: 632-636.

Mielzynska-svach, D., Blaszczyk, E., Butkiewicz, D., Durzynska, J. and Rydzanicz, M. (2013). Influence of genetic polymorphisms on biomarkers of exposure and effects in children living in Upper Silesia. Mutagenesis 28: 591-599.

Mohammadyan, M., Alizadeh-larimi, A., Etemadinejad, S., Latif, M.T., Heibati, B., Yetilmezsoy, K. and Abdulwahab, S.A. (2017). Particulate air pollution at schools: Indoor-outdoor relationship and determinants of indoor concentrations. Aerosol Air Qual. Res. 17: 857-864.

Muhamad Daud, S.A., Jalaludin, J. and Sopian, N.A. (2018). Air pollutants exposure and frequency of micronuclei (MN) among primary school children nearby industrial Area. Mal. J. Med. Health Sci. 14: 56-62.

Pan, B.J., Hong, Y.J., Chang, G.C., Wang, M.T., Cinkotai, F.F. and Ko, Y.C. (1994). Excess cancer mortality among children and adolescents in residential districts polluted by petrochemical manufacturing plants in Taiwan. $J$. Toxicol. Environ. Health 43: 117-129.

Pedersen, M., Wichmann, J., Autrup, H., Dang, D.A., Decordier, I., Hvidberg, M., Bossi, R., Jakobsen, J., Loft, S. and Knudsen, L.E. (2009). Increased micronuclei and bulky DNA adducts in cord blood after maternal exposures to traffic-related air pollution. Environ. Res. 109: 10121020.

Prieto-parra, L., Yohannessen, K., Brea, C., Vidal, D., Ubilla, C.A. and Ruiz-rudolph, P. (2017). Symptoms in asthmatic and non-asthmatic children in Santiago, Chile. Environ. Int. 101: 190-200.

Rovira, E., Cuadras, A., Aguilar, X., Esteban, L., BorràsSantos, A., Zock, J.P. and Sunyer, J. (2014). Asthma, respiratory symptoms and lung function in children living near a petrochemical site. Environ. Res. 133: 156-163.

Rusconi, F., Catelan, D., Accetta, G., Peluso, M., Pistelli, R., Barbone, F., Di Felice, E., Munnia, A., Murgia, P., Paladini, L., Serci, A. and Biggeri, A. (2011). Asthma symptoms, lung function, and markers of oxidative stress and inflammation in children exposed to oil refinery pollution. J. Asthma 48: 84-90.

Seifi, M., Niazi, S., Johnson, G., Nodehi, V. and Yunesian, M. (2019). Exposure to ambient air pollution and risk of childhood cancers: A population-based study in Tehran, Iran. Sci. Total Environ. 646: 105-110.

Silva da Silva, C., Marzari Rossato, J., Aparecida Vac Rocha, J. and Vargas, V.M.F. (2015). Characterization of an area of reference for inhalable particulate matter $\left(\mathrm{PM}_{2.5}\right)$ associated with genetic biomonitoring in children. Mutat. Res. Toxicol. Environ. Mutagen. 778: 44-55.

Sisenando, H.A., de Medeiros, S.R.B., Artaxo, P., Saldiva, P.H.N. and de Souza Hacon, S. (2012). Micronucleus frequency in children exposed to biomass burning in the Brazilian Legal Amazon region: A control case study. BMC Oral Health 12: 1-7. 
Smargiassi, A., Kosatsky, T., Hicks, J., Plante, C., Armstrong, B., Villeneuve, P.J. and Goudreau, S. (2009).

Risk of asthmatic episodes in children exposed to sulfur dioxide stack emissions from a refinery point source in Montreal, Canada. Environ. Health Perspect. 117: 653659.

Sopian, N.A., Jalaludin, J. and Mohd Tamrin, S.B. (2016). Risk of respiratory health impairment among susceptible population living near petrochemical industry-A review article. Iran J. Public Health 45: 9-16.

Sopian, N. and Jalaludin, J. (2017). The application of biomarker in determining genotoxic potential of polyaromatic hydrocarbon exposure among children. Ann. Trop. Med. Public Health 10: 533-543.

Suhaimi, N.F., Jalaludin, J. and Abu Bakar, S. (2017). Cysteinyl leukotrienes as biomarkers of effect in linking exposure to air pollutants and respiratory inflammation among school children. Ann. Trop. Med. Public Health. 10: 423-431.

Suhaimi, N.F., Jalaludin, J. and AbuBakar, S. (2015). Association between school and residential air pollutants with respiratory symptoms among school children at an industrial area. Adv. Environ. Biol. 9: 77-86.

Tan, C., Lu, S., Wang, Y., Zhu, Y., Shi, T., Lin, M., Deng, Z., Wang, Z., Song, N., Li, S., Yang, P., Yang, L., Liu, Y., Chen, Z. and Xu, K. (2017). Long-term exposure to high air pollution induces cumulative DNA damages in traffic policemen. Sci. Total Environ. 593-594: 330-336.

Thomas, P., Holland, N., Bolognesi, C., Kirsch-volders, M., Bonassi, S., Zeiger, E., Knasmueller, S. and Fenech, M. (2011). Buccal micronucleus cytome assay. Nat. Protoc. 4: 825-837.

Tsai, S., Tiao, M.M., Kuo, H.W., Wu, T.N. and Yang, C.Y. (2009). Association of bladder cancer with residential exposure to petrochemical air pollutant emissions in Taiwan. J. Toxicol. Environ. Health Part A 72: 53-59.

Vanker, A., Barnett, W., Nduru, P.M., Gie, R.P., Sly, P.D. and Zar, H.J. (2015). Home environment and indoor air pollution exposure in an African birth cohort study. Sci. Total Environ. 536: 362-367.

Wichmann, F.A., Mu, A., Busi, L.E., Cianni, N., Massolo, L. and Schlink, U. (2009). Increased asthma and respiratory symptoms in children exposed to petrochemical pollution. J. Allergy Clin. Immunol. 123: 632-638.

Wichmann, J., Lind, T., Nilsson, M.A. and Bellander, T. (2010). $\mathrm{PM}_{2.5}$, soot and $\mathrm{NO}_{2}$ indoor-outdoor relationships at homes, pre-schools and schools in Stockholm, Sweden. Atmos. Environ. 44: 4536-4544.

World Health Organization (WHO) (2006). WHO Air quality guidelines for particulate matter, ozone, nitrogen dioxide and sulfur dioxide. Switzerland. http://apps.who. int/iris/bitstream/handle/10665/69477/WHO SDE PHE OEH_06.02_eng.pdf,sequence $=1$, Last Access: $1 \overline{4}$ June $\overline{2} 018$.

Yang Razali, N.Y., Latif, M.T., Dominick, D., Mohamad, N., Sulaiman, F.R. and Srithawirat, T. (2015). Concentration of particulate matter, $\mathrm{CO}$ and $\mathrm{CO}_{2}$ in selected schools in Malaysia. Build. Environ. 87: 108116.

Yang, J., Nam, I., Yun, H., Kim, J., Oh, H., Lee, D., Jeon, S., Yoo, S. and Sohn, J. (2015). Characteristics of indoor air quality at urban elementary schools in Seoul, Korea: Assessment of effect of surrounding environments. Atmos. Pollut. Res. 6: 1113-1122.

Yang, L., Haifeng, W., Shanshan, W., Lei, Z. and Qi, Z. (2017). The correlation between indoor and outdoor particulate matter of different building types in Daqing, China. Procedia Eng. 205: 360-367.

Yu, C.L., Wang, S.F., Pan, P.C., Wu, M.T., Ho, C.K., Smith, T.J., Li, Y., Pothier, L.J. and Christiani, D.C. (2005). No association between residential exposure to petrochemicals and brain tumor risk. Cancer Epidemiol. Biomarkers Prev. 14: 3007-3009.

Yuan, T., Shen, Y., Shie, R., Hung, S., Chen, C. and Chan, C. (2018). Increased cancers among residents living in the neighborhood of a petrochemical complex: A 12-year retrospective cohort study. Int. J. Hyg. Environ. Health. 221: 308-314.

Received for review, December 25, 2019 Revised, February 25, 2020 Accepted, February 28, 2020 